\title{
DIFFERENCES ABILITY OF PROBLEM SOLVING AND SELF - EFFICACY STUDENT MATH OF LEARNING JIGSAW BASED CULTURE OF BATAK TOBA WITH DIRECT LEARNING
}

\author{
Dian Raesita Sitio ${ }^{1}$ \\ College student, Graduate Program School in Mathematics \\ Universitas Negeri Medan \\ Medan, Indonesia \\ Email: meryancesiagian@yahoo.com
}

\author{
Edy Surya ${ }^{2}$ \\ Lecturer, Graduate Program School in Mathematics \\ Universitas Negeri Medan \\ Medan, Indonesia
}

\begin{abstract}
The research objective in the design of experiments investigating the apparent difference in the increase in Capacity of mathematical problem solving and self-efficacy students mathematics students. This research was conducted at SMP Negeri 1 Jorlang Hataran as many as 48 students. This research is an experimental study with pre-test-post-test control group design . The population in this study were all students of class VIII by taking samples of two classes (experimental class 1 and experiment class 2) through random sampling technique. Data were analyzed by ANACOVA test . Prior to ANACOVA test, homogeneity test in the research and normality in this research with $5 \%$ significant level. The result of data analysis shows that the average of $\mathrm{N}$-Gain test of problem solving ability of experiment class 1 is 0,5706 and experiment class 2 is 0,4477 with value sig $=0$, with $0<\alpha=0,05$ hence there is difference of improvement of capability mathematical problem solving of students taught by Cooperative Learning Jigsaw Type Based Batak Toba Culture with Direct Learning. Average N-Gain selfefficacy test experiment 1 and experiment 2 is 0.4813 and 0.3082 with -value (2-tailed) is 0 , with $0<\alpha=0.05$ then there is a difference in the increase of self-efficacy capability students taught by Cooperative Learning Jigsaw Type Based Batak toba Culture and Direct Learning.
\end{abstract}

Keywords: Cooperative Learning of Jigsaw Type Based Batak Toba Culture, Mathematical Problem Solving, Self-efficacy.

\section{INTRODUCTION}

Education is a very important requirement in the life of society, nation and the land of water. The advancement of a nation is determined by the nation's own educational creativity. Education requires a continuous change. Changes made play a role to make the improvement that becomes a necessity as the achievement of the objectives of the curriculum.

Education requires many facilities and good educational personnel to support the achievement of educational goals. As stated by Hamalik (2013: 3-4) that:

"All educational activities, ie teaching guidance, and / or training are directed towards achieving educational goals. In this context, the purpose of education is a component of the educational system that occupies central position and function.
That is why, every educational personnel need to understand well the purpose of education in order to try to carry out its duties and functions to achieve the predetermined educational goals ".

Mathematics is one of the areas of study that occupy an important role in education. One of the things that showed the statement was seen from the many hours of mathematics at school compared to other fields of study. The field of study of mathematics is given at every level of education to prepare students in the face of the development of a world that is more advanced and growing rapidly.

There are many reasons for the importance of the learner To study mathematics, one of them according to Cockroft (Abdurrahman, 2003; Eviyanti, Surya, \& Syahputra, 2017) says that math is important to teach students because: (1) always used in life, (2) all (4) can be used to present information by all means, (5) improve logical thinking ability, accuracy, awareness, and spatial, (6) provide satisfaction to problem-solving attempts to challenge. Many of the reasons the school needs to teach math to students, in essence on daily problems.

According to De Lange (in Hoiriyah, 2017) there are 8 competencies that must be learned and mastered by students during the learning process of mathematics in the classroom are: (1) thinking and reasoning systematically; (2) to be mathematical; (3) communicating systematically; (4) modeling; (5) compile and solve problems; (6) represents; (7) symbolize; (8) master the tools and technology.

Solving problems is the process of applying the previously acquired knowledge of new and different situations. Although problem solving is an integral part of mathematical problems, many students still find it difficult to solve math problems. It is continued with the statement of Shahbari, Daher, and Rasslan (in Ritonga, Surya, Syahputra 2017 ) "Ability to solve word problems falls far beyond their ability to compute by the way do not know how to choose the correct operation to apply to the problem". The ability to solve problems is still far below their ability to calculate because children do not know how to choose the correct operation to apply to the problem. 
In addition to problem-solving skills, self-efficacy is also part of the researcher's focus. Self-efficacy is a belief about the probability that one can execute successfully some action or future and achieve some results. Zuya, Kwalat and Attah (2016) define that self-efficacy means belief in one's potential. Gavora (in Zuya, Kwalat and Attah 2016) defines self-efficacy as a person's belief about their ability to perform certain tasks in an appropriate and effective way. Han, Liou-Mark, Yu and Zeng (2015) define self-efficacy as a person's belief or perception of one's ability to perform at a certain level on a task. Self-efficacy is defined as people's beliefs about their abilities and about themselves (Schwarzer, 1992; in Yousaf, 2015).

From the above problems, it is necessary to apply a model of mathematical learning which is expected to solve the problems faced by the students. As Durowoju and Onuka (2015) put it, "In the knowledge industry, teachers are leaders during the teaching and learning process. Thus, his role in instilling Knowledge into learning can not be overemphasized. Teachers teach in schools, provide information and instruct students on how to do things the right way and best. "

Jigsaw type cooperative learning model is a cooperative learning model that maximizes the learning process with a team of experts. Each student in the group has the expertise of the sub subject being studied and has the responsibility to share it with other members in one group. Every student in one group does not have an awkward sense of asking because the teacher is his or her own friend. This type of learning can improve learning outcomes, as it increases motivation to learn. Umi (in Saila, 2013) "Jigsaw type cooperative learning is one type of cooperative learning. The technique of teaching jigsaw was developed by Aronson et.al as a cooperative learning method. In jigsaw type cooperative learning, students are divided into several groups, one group consisting of several members who are responsible for mastering the learning component and being able to teach that part to other members of the group."

Indonesia has a very high cultural diversity. Moreover in the area of North Sumatra. Batak culture in the area of North Sumatra is also still divided, namely: Toba, Simalungun, Karo, Pakpak, and Nias. But researchers focused their research on Batak toba culture. Researchers choose the culture of Batak Toba is due to research conducted in SMP Negeri 1 Jorlang Hataran majority Batak Toba.

In a journal by Pratiwi (2016) it is said: "There are a number of elementary schools in Kudus where students combine students of Javanese descent with ethnic Chinese Chinese descent. students of ethnic Chinese descent only want to mingle with fellow class. This is seen during the learning process when the teacher asks the students to do the tasks in groups. The existence of differences in cultural background (multicultural culture) makes an influence in the learning process."

Therefore, the researcher intends to open the students' minds that the diverse Indonesian culture is something to be grateful for, not to be differentiated and closed. The introduction of batak toba culture to students who are not batak people will also make them understand that the culture is a beautiful and interesting work. Batak culture is also considered to be highly correlated with problem-solving skills and student self-efficacy. In this jigsaw cooperative learning will be shown that the formation of each team is not grouping students only with similar tribes only. In SMP Negeri 1 Jorlang Hataran not all students are Batak tribe, but it can be said the majority is Batak tribe.

From the description of the explanation, researchers feel it is important to study whether jigsaw type cooperative learning can improve problem solving skills and mathematical selfefficacy which will ultimately improve students' mathematics learning outcomes.

\section{RESEARCH METHOD}

The population in this study is all students of class VIII SMP Negeri 1 Jorlang Hataran, as the subject of the sample in this study, randomly selected two classes of nine classes in the SMP. From the random selection, then elected students of class VIII-1 and VIII-9 which then randomly selected also experiment class 1 and experiment class 2 . In this research, VIII-1 is selected as experimental class and VIII-9 as experiment class 2 , with the number of students in class VIII-1 as many as 24 students and class VIII-9 as many as 24 students.

This type of research is quasi experiment (quasi experiment) because the class used has been formed before. The design used in this study was an experimental design with a pretest and control group postes:

TABLE 1. Research Design

\begin{tabular}{|l|l|l|l|}
\hline Group & Pretes & Treatment & Postest \\
\hline Experiment 1 & O1 & $\mathrm{X} 1$ & $\mathrm{O} 2$ \\
\hline Experiment 2 & $\mathrm{O} 1$ & $\mathrm{X} 2$ & $\mathrm{O} 2$ \\
\hline
\end{tabular}

Information:

O1: Pretest test

O2: Test postes

X1: Given cooperative learning type Jigsaw Based Toba Batak Culture

X2: Being treated directly

In this study there are two groups of students in each class that will be compared. One group of students will be given treatment by using cooperative learning type jigsaw based on batak toba culture and the other using direct learning.

To know the ability of problem-solving ability and selfefficacy of student, hence students are given postes, both classes are given treatment using cooperative type jigsaw learning based on batak toba culture and ordinary learning.

To know the improvement of problem solving ability and student self-efficacy, students are given pretest and postes, in the class given treatment by using cooperative learning type jigsaw based on batak toba culture.

The improvement of students' mathematical problem solving ability is seen from the result of $n$-gain calculation in experiment class 1 and experiment class 2 . The result of $n$-gain calculation in experiment class 1 and experiment 2 class are in the following table: 
TABLE 2. N-Gain Calculation Result Mathematics Problem Solving Test Group Statistics

\begin{tabular}{|cc|c|c|c|c|}
\hline & CLASS & $\mathrm{N}$ & Mean & Std. Deviation & $\begin{array}{c}\text { Std. Error } \\
\text { Mean }\end{array}$ \\
\hline Gain & CLASS & 24 & .5706 & .06270 & .01280 \\
& EKS 1 & & & & \\
CLASS & 24 & .4477 & .06515 & .01330 \\
EKS 2 & & & & \\
\hline
\end{tabular}

The n-gain value of the students ' solving ability in the experimental class 1 is higher than the experimental class 2 that is 0,5706 and 0,4477 so that there is a difference in the improvement of students' mathematical problem solving in the experimental class 1 and the experimental class 2 by 0,1229 .

The high average n-gain of problem-solving test results in experimental class 1 rather than experiment 2 class shows that the difference in the improvement of students' mathematical problem solving abilities in experimental class 1 given cooperative learning type jigsaw based on Batak Toba culture is better than experimental class 2 given direct learning. Increased self-efficacy mathematics students seen from the results of the calculation of n-gain in the experimental class 1 and experimental class 2 . The results of $n$-gain calculations in experimental class 1 and experiment 2 class are contained in the following table:

TABLE 3. N-Gain Calculation Results Self-Efficacy Tests Mathematics Group Statistics

\begin{tabular}{|ll|c|c|c|c|}
\hline & CLASS & $\mathrm{N}$ & Mean & Std. Deviation & $\begin{array}{c}\text { Std. Error } \\
\text { Mean }\end{array}$ \\
\hline Gain & CLASS EKS 1 & 24 & .4813 & .19948 & .04072 \\
& CLASS EKS 2 & 24 & .3082 & .14905 & .03043 \\
\hline
\end{tabular}

The $\mathrm{n}$-gain value of the students ' self-efficacy test in the experimental class 1 is higher than the experimental class 2 that is 0.4813 and 0,3082 , so there is a difference in the improvement of students' mathematical problem solving skills in the experimental class 1 and experiment 2 of 0,1731 . The high $\mathrm{n}$-gain average of the self-efficacy test results in the experimental class 1 rather than the experimental class 2 shows that differences in self-efficacy mathematics of students in experimental class 1 who were given type jigsaw cooperative learning based on Batak Toba culture were better than experimental class 2 given by direct learning.

\section{RESULTS AND DISCUSSION}

In this section will describe the description and interpretation of research data. Descriptions and interpretations were made on the ability of mathematical problem solving, mathematical mathematical self-efficacy abilities and patterns of student answers in solving the given problem. Factors involved in the research are learning factor and problem solving factor factor and mathematical self-efficacy of student mathematics.

\section{a. Learning Factors}

The result of the research which has been described previously shows that there is a difference of problem solving ability and mathematical mathematical self-efficacy between students who are given cooperative learning type jigsaw with direct instruction. Similarly, the pattern of answers of students who are taught by cooperative learning jigsaw type higher than the pattern of student answers are taught by direct instruction.

\section{b. Ability to Solve Mathematical Problems}

Problem-solving skills are the ability of students to understand problems, plan solutions, perform calculations and re-examine them. The results showed that the average score of problem-solving ability with problem-based learning was much higher than that of the direct teaching class.

Based on the results of data analysis of the average pretest score conducted on the group of students who received learning through cooperative learning type of jigsaw culturebased batak with an average of 12,79 and the group of students who received learning only through Direct Learning with an average of 13,16 . From the results of testing the pretest score data of both groups can be concluded that both groups have the same initial ability.

After the jigsaw type cooperative learning based on Batak culture for experimental class 1 and Direct learning for experimental class 2, the postes score was obtained for mathematical problem solving ability in both classes. The mean postes score of the problem solving ability of the experimental mathematical problem of the experimental class 1 students was 42,04 as well as the mean score of students' mathematical problem solving abilities in the control class was 36,25 .

\section{c. Ability Self- E fficacy}

The results show that the initial self-efficacy variance analysis in the experimental class 1 has an average 61,08 and in experiment class 2 amount 61,16 From the results of the test data the average score of self-efficacy against both groups can be concluded that both groups have the same initial ability. While the increase can be seen from the constant of regression equation for cooperative type of jigsaw that is 78,58 whereas direct learning 71,95. It can be concluded that there are differences in mathematical self-efficacy between students who are given cooperative learning type jigsaw with direct learning on the subject of building a flat side space.

\section{Suggestion}

Based on the research results, jigsaw type cooperative learning applied to the learning activities provides important things for improvement. For that researchers suggest some of the following:

a. Jigsaw type cooperative learning in mathematics learning that emphasizes the problem solving skills and mathematical self-efficacy of student mathematics can be used as an alternative to apply innovative learning mathematics especially in teaching material system of linear equations 
b. Learning tools produced can be used as a comparison for teachers in developing learning tools of mathematics with jigsaw type cooperative learning on the subject of the system of linear equations

c. It is expected that teachers need to add insight about theories of learning and innovative learning model in order to implement it in the learning of mathematics so that regular learning can be consciously abandoned as an effort to improve student learning outcomes.

\section{REFERENCES}

[1] Eviyanti, C,. Surya, E,. \& Syahputra, E. 2017. An Analysis of Students Problem Solving Ability on Opportunities Material in IX Grade SMPN 6 Langsa. International Journal of Sciences: Basic and Applied Research (IJSBAR). Vol. 33, No. 2, pp. 57-67

[2] Hamalik, O. 2013. Kurikulum dan Pembelajaran. Bumi Aksara: Jakarta

[3] Hoiriyah, D. 2017. Peningkatan Kemampuan Pemecahan Masalah Matematik dan Self-Efficacy Siswa Melalui Pembelajaran Berbasis Masalah: UNIMED

[4] Pratiwi, I. 2016. Penerapan Model Pembelajaran Jigsaw Untuk Meningkatkan Hasil Belajar Ips Berbasis Multikultural. Jurnal Konseling GUSJIGANG Vol. 2, No. 1, pp. 111-119

[5] Ritonga, E,. Surya, E and Syahputra E. 2017. Development of Learning Devices Oriented Model Eliciting Activities to Improve Mathematical Problem Solving Ability Junior High School Students. International Journal of Sciences: Basic and Applied Research. Vol. 33, No. 3, pp. 4252.

[6] Saila. 2013. Peningkatan Kemampuan Pemecahan Masalah Matematik dan Self-Efficacy Siswa Melalui Pembelajaran Berbasis Masalah: UNIMED.

[7] Zuya, H., Kwalat, S., Attah, B,. 2016. Pre-service Teachers' Mathematics Self-efficacy and Mathematics Teaching Self-efficacy. University of Jos, Nigeria. 